\title{
Wear of Media Balls during the Ball Milling of $\mathrm{Si}_{3} \mathrm{~N}_{4}$ Powder
}

\author{
Hideyuki MASAKI and Shigetaka WADA \\ Toyota Central R \& D Labs. Inc., Nagakute, Aichg-gun, Aichi 4 480-11 \\ 窒化ケイ素のボールミル粉砕におけるボールの摩耗 \\ 正木英之・和田重孝 \\ (株)豊田中央研究所, 480-11 愛知県愛知郡長久手町
}

[Received June 29, 1992; Accepted September 22, 1992]

\begin{abstract}
Wear of six kinds of media balls during the ball milling of $\mathrm{Si}_{3} \mathrm{~N}_{4}$ raw powder with additives was tested. The materials of the ball were $\alpha^{\prime} / \beta^{\prime}$-SiAlON, $\beta-\mathrm{Si}_{3} \mathrm{~N}_{4}$, high purity $\mathrm{Al}_{2} \mathrm{O}_{3}, \mathrm{Al}_{2} \mathrm{O}_{3}\left(\mathrm{HD}-11\right.$ ), $\mathrm{SiC}$ and tetragonal $\mathrm{ZrO}_{2}$. The material of the least wear was $\alpha^{\prime} / \beta^{\prime}$-SiAlON. The $\mathrm{Si}_{3} \mathrm{~N}_{4}$ powder milled with $\mathrm{SiC}$ ball resulted in the mixture of $\mathrm{Si}_{3} \mathrm{~N}_{4}$ with $13 \mathrm{vol} \%$ of $\mathrm{SiC}$. The powder consolidated to almost full density by the conventional gas pressure sintering.
\end{abstract}

Key-words : Wear, Media ball, Ball milling, $S i_{3} N_{4}, \alpha^{\prime} / \beta^{\prime}$ SiAlON.

1. Introduction

The particle size reduction and homogeneous mixing of raw powder in the ball milling process generally affect the sinterability of the milled powder and the properties of the sintered material using the powder. A few papers have reported the particle size reduction of $\mathrm{Si}_{3} \mathrm{~N}_{4} \cdot{ }^{1)-4}$ ) As far as we have searched, however, there are no papers on the wear of the medium ball. One of the important factors affecting the quality of ceramics through the ball milling is contamination by wear from the media and mill. The purposes of this study are to measure the wear of the media and mill, especially the media balls, during the ball milling of $\mathrm{Si}_{3} \mathrm{~N}_{4}$ raw powder with additives and to evaluate the effects of the contamination on the bending strength of sintered $\mathrm{Si}_{3} \mathrm{~N}_{4}$ made of the powders milled.

\section{Experimental}

\subsection{Materials of the media ball}

Six kinds of media balls used in this study are shown in Table 1. $\alpha^{\prime} / \beta^{\prime}$-SiAlON was expected to be excellent in wear when it was used as a medium ball, since the composite SiAlON is excellent in erosive wear because of its high hardness and large fracture toughness. ${ }^{5)}$ Ball $\mathrm{B}$ is made of $\beta-\mathrm{Si}_{3} \mathrm{~N}_{4}$ including 8 $\mathrm{wt} \%$ of spinel $\left(\mathrm{MgAl}_{2} \mathrm{O}_{4}\right)$ as an additive. Ball $\mathrm{F}$, made of $\mathrm{TZP}-\mathrm{ZrO}_{2}(\mathrm{Z100})$ which is the most popular medium material for milling $\mathrm{BaTiO}_{3}, \mathrm{PZT}$ and other electronic ceramics, was used in this experiment for comparison. SiC, used for ball E, was selected as the material having the highest hardness. $\mathrm{Al}_{2} \mathrm{O}_{3}$, used for balls $\mathrm{C}$ and $\mathrm{D}$, is the most popular medium materi- al and was used for comparing the wear with that of $\mathrm{Si}_{3} \mathrm{~N}_{4}$.

\subsection{Milling conditions}

The milling conditions are shown in Table 2. The material of the mill is $\alpha^{\prime} / \beta^{\prime}-\mathrm{Si}_{3} \mathrm{~N}_{4}$ the same as that of ball $\mathrm{B}$, and the weight of the mill is $4.5 \mathrm{~kg}$. The raw powder is the mixture of $\mathrm{Si}_{3} \mathrm{~N}_{4}$ (ESP, Ube Industries Ltd.), $\mathrm{Y}_{2} \mathrm{O}_{3}$ (YF, Mitsubishi Chemical Industries Ltd.) and $\mathrm{Al}_{2} \mathrm{O}_{3}$ (AKP-20, Sumitomo Chemical Co., Ltd.). Three kinds of the raw powders were weighted at the ratio shown in Table 2 , and then mixed in a juicer type mixer for a few minutes. The specific surface area of the mixed powder before milling was $6.1 \mathrm{~m}^{2} / \mathrm{g}$.

The bulk volume of the media ball was $50 \%$ of the mill volume. The total weight of each ball was $4.4 \mathrm{~kg}$ for balls $\mathrm{A}, \mathrm{B}$ and $\mathrm{E}, 5.5 \mathrm{~kg}$ for balls $\mathrm{C}$ and $\mathrm{D}$, and $8.1 \mathrm{~kg}$ for ball $\mathrm{F}$. The volume of the space between balls was about $40 \%$ of the volume of the balls, that is about $20 \%\left(900 \mathrm{~cm}^{3}\right)$ of the volume of the mill.

Table 1. Density, Vickers hardness and fracture toughness of balls tested.

\begin{tabular}{|c|c|c|c|c|}
\hline & Material & $\begin{array}{c}\text { Density }{ }^{* 1} \\
\left(\mathrm{~g} / \mathrm{cm}^{3}\right)\end{array}$ & $\begin{array}{c}\text { Vickers }{ }^{* 2} \\
\text { hardness } \\
\text { (GPa) }\end{array}$ & $\begin{array}{l}\text { Fracture }{ }^{* 3} \\
\text { toughness } \\
\quad\left(\text { MPan }^{1 / 2}\right)\end{array}$ \\
\hline A & $\alpha^{\prime} / \beta^{\prime}$ sialon & 3.24 & 18.8 & 5.7 \\
\hline B & $\beta-\mathrm{Si}_{3} \mathrm{~N}_{4}$ & 3.13 & 15.1 & 5.7 \\
\hline C & $\mathrm{Al}_{2} \mathrm{O}_{3}(\mathrm{SSA}-999 \mathrm{w})$ & 3.96 & 17.4 & 3.2 \\
\hline D & $\mathrm{Al}_{2} \mathrm{O}_{3}(\mathrm{HD}-11)$ & 3.61 & 13.7 & 3.7 \\
\hline E & $\mathrm{SiC}$ & 3.16 & 26.6 & 2.6 \\
\hline $\mathrm{F}$ & $\mathrm{ZrO}_{2}(\mathrm{Z} 100)$ & 6.07 & 12.7 & 4.4 \\
\hline
\end{tabular}

Table 2. Experimental condition.

\begin{tabular}{ll}
\hline Mill & $\phi 170 \times \mathrm{L} 200(\mathrm{~mm}), 4500 \mathrm{~cm}^{3}$ \\
\hline Ball & $5 \mathrm{~mm}$ sphere, $2250 \mathrm{~cm}^{3}(\mathrm{Half}$ a volume of the pot) \\
& Kinds of ball is shown in table 1 \\
\hline Liquid & $800 \mathrm{~cm}^{3}$ of ethano1 \\
\hline Powder & $\mathrm{Si}_{3} \mathrm{~N}_{4}$ with $5 \mathrm{wt} \% \mathrm{Y}_{2} \mathrm{O}_{3}$ and $3 \mathrm{wt} \% \mathrm{Al}_{2} \mathrm{O}_{3}$ \\
& $320 \mathrm{~g}$ of the mixed powder \\
\hline Rotation speed & $110 \mathrm{rpm}$ (about $50 \%$ of critical speed) \\
\hline Time & $72 \mathrm{hr}$ \\
\hline
\end{tabular}


The quantities of the raw powder and ethanol as a milling fluid were determined so that the total volume of the powder and fluid is almost equal to that of the space between the media balls. The volume ratio of the powder vs. the fluid is $1: 8$. When the quantity of the powder increased more than the volume ratio, the mixed slurry was difficult to separate from the media balls because of the high viscosity of the slurry. The rotation speed of the mill was set at $110 \mathrm{rpm}$ which is about $50 \%$ of the critical speed $^{6)}$ and is supposed to be also the most effective speed to reduce the particle size. ${ }^{7)}$

\section{Results and discussion}

The loss in the weight of the medium ball and that of the mill are shown in Table 3. The weight loss is almost in proportion to the milling time, which is omitted here. When the mill was rotated only with the medium ball and ethanol except powders, the weight losses of the balls ranged from 0.2 to $93.1 \mathrm{~g}$ and the order of wear was $\mathrm{D}>\mathrm{E}>\mathrm{C}>\mathrm{B}>\mathrm{A}>\mathrm{F}$. In these cases, the wear of balls seems to start by the chipping of balls itself and then the chips multiplicate to wear. Assuming this mechanism, it is acceptable that above order of wear was roughly in inverse proportion to the fracture toughness of the balls. The weight loss of the mill was smaller than the limit of weight measurement. When the milling was performed with $\mathrm{Si}_{3} \mathrm{~N}_{4}$ powder, the weight losses of the balls increased to 3.3-214.5 $\mathrm{g}$ and the order of wear became $\mathrm{F}>\mathrm{D}>\mathrm{E}>\mathrm{C}>\mathrm{B}>\mathrm{A}$. The ratio of the weight loss between $\mathrm{A}$ and $\mathrm{F}$ was 65 times. The weight loss of the mill was not so large as that of the ball, $0.9-2.1 \mathrm{~g}$, and it did not change too much by the kind of balls. Comparing Tables 1 and 3 , it may be considered that the quantity of the loss in the weight of the ball strongly depends on the hardness and fracture toughness of the ball. The most highly wearresistant ball $\mathrm{A}$, made of $\alpha^{\prime} / \beta^{\prime}$-SiAlON, has relatively high hardness, $18.8 \mathrm{GPa}$, and large $K_{1 \mathrm{c}}, 5.7 \mathrm{MPa}$. $\mathrm{m}^{1 / 2}$. The serious wear of $\mathrm{ZrO}_{2}$, ball $\mathrm{F}$, is assumed to be due to its low hardness. The crystal phase of $\mathrm{Si}_{3}$ $\mathrm{N}_{4}$ raw powder (ESP) is almost of $\alpha$-type. The hardness of $\alpha-\mathrm{Si}_{3} \mathrm{~N}_{4}, 23 \mathrm{GPa}$, is remarkably larger than that of $\mathrm{ZrO}_{2}$, then the wear caused by the scratching mechanism seemed to work easily. ${ }^{8)} \mathrm{Al}_{2} \mathrm{O}_{3}$ (HD-11)

Table 3. Weight of balls and mill after $72 \mathrm{~h}$ milling with or without $\mathrm{Si}_{3} \mathrm{~N}_{4}$ powder with additives.

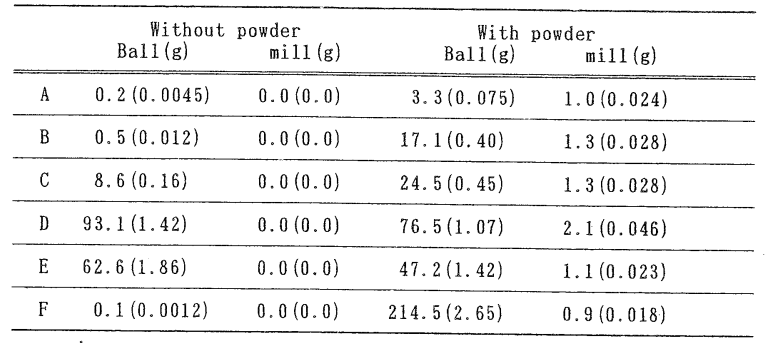

* Number in parenthesis is weight loss percentage to the initial weigh of balls or a mill. was subjected to much wear also due to its low hardness. The hardness of $\mathrm{SiC}$ is larger than that of $\alpha^{\prime} / \beta^{\prime}$ SiAlON, but the fracture toughness of $\mathrm{SiC}$ is the smallest among the six balls. The wear of $\mathrm{SiC}$ is supposed to be due to its frangibility. However, the analysis, which correlates the volume loss $(V)$ with the hardness $\left(H_{\mathrm{v}}\right)$ and the fracture toughness $\left(K_{1 \mathrm{c}}\right)$ supposing the equation $V \propto H_{\mathrm{v}}{ }^{a} K_{1 \mathrm{c}}{ }^{b}$ and using the multiple regression analysis, resulted in a contradiction and could not obtain an experimental equation, namely, the wear is neither controlled by one mechanism nor governed only by the hardness and the fracture toughness.

Comparing the amount of wear of balls with and without powder, the wear with powder are more than that of without powder in balls A, B, C and F. On the contrary, the wear without powder are more than that of with powder in balls D and $\mathrm{E}$. It is supposed that relatively large $\mathrm{Al}_{2} \mathrm{O}_{3}$ chips from ball $\mathrm{D}$ and $\mathrm{SiC}$ chips, which is harder than $\mathrm{Si}_{3} \mathrm{~N}_{4}$, resulted in more wear of balls than that with $\mathrm{Si}_{3} \mathrm{~N}_{4}$ powder. The size of chips from ball D was not measured directly, however a little smaller specific surface area of milled powder by ball $\mathrm{D}$ than that by other balls in Table 4 suggests relatively large $\mathrm{Al}_{2} \mathrm{O}_{3}$ chips from ball D.

The specific surface area of the milled powder and the wear of balls increased linearly in proportion to the milling time. ${ }^{7)}$ The specific surface area of the milled powders including powders worn from the ball and the mill were about $24 \mathrm{~m}^{2} / \mathrm{g}$ except the case of ball D, as shown in Table 4. Measuring the size of the milled powder and the powder worn from the equipment separately will give us some interesting information, though we could find no easy ways to separate the powders. The average diameters of the powders milled with balls $\mathrm{A}$ and $\mathrm{B}$ and measured with laser scattering type particle size distribution analyzer (Horiba, LA-700) were $0.51 \mu \mathrm{m}$, and it did not accord with the equivalent sphere diameter of $0.08 \mu \mathrm{m}$ calculated from the specific surface area.

Table 4. Specific surface area of the $\mathrm{Si}_{3} \mathrm{~N}_{4}$ powder with additive after $72 \mathrm{~h}$ milling and bending strength of sintered body made of the milling powders.

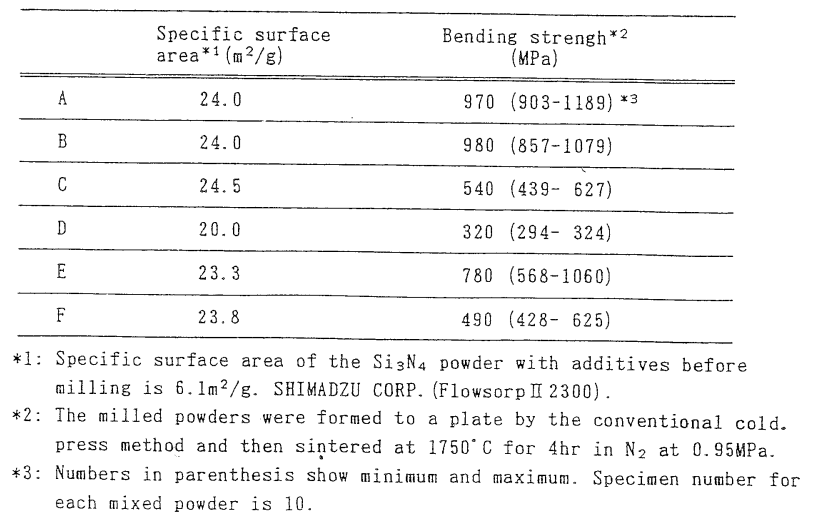


The diameter of the powders observed in SEM was about $0.3 \mu \mathrm{m}$.

The milled powders were dried, formed to a plate by the conventional cold press method, and then sintered at $1750^{\circ} \mathrm{C}$ for $4 \mathrm{~h}$ in $\mathrm{N}_{2}$ at $0.95 \mathrm{MPa}$. Specimens of $3 \times 4 \times 40(\mathrm{~mm})$ were cut out from the sintered plates, and the four-point bending strength was measured in conformity with JIS R-1601. In the cases of $\mathrm{A}$ and $\mathrm{B}$, relatively large bending strengths, such as $970 \mathrm{MPa}$ and $980 \mathrm{MPa}$, were obtained because the composition did not change so much. In the cases of $\mathrm{C}, \mathrm{D}$ and $\mathrm{F}$, more than $7 \mathrm{wt} \%$ of $\mathrm{Al}_{2} \mathrm{O}_{3}$ or $40 \mathrm{wt} \%$ of $\mathrm{ZrO}_{2}$ contaminated, then the bending strength were smaller than $60 \%$ comparing with cases $\mathrm{A}$ and $\mathrm{B}$.

In the case of $\mathrm{E}$, a valuable hint was received. The milled powder including 13 vol\% of SiC consolidated to almost full density $\left(3.23 \mathrm{~g} / \mathrm{cm}^{3}\right)$ by the abovementioned conventional gas pressure sintering. Generally, $\mathrm{Si}_{3} \mathrm{~N}_{4}$ composite with more than 10 vol\% of $\mathrm{SiC}$ cannot be sintered to nearly full density without high pressure, and it is usually consolidated by hot-pressing or hot-isostatic pressing. ${ }^{9)-11)}$ The case $\mathrm{E}$ suggests that $\mathrm{Si}_{3} \mathrm{~N}_{4}-\mathrm{SiC}$ composite including more than 10 vol\% of $\mathrm{SiC}$ can be consolidated by the conventional sintering when raw powders are milled to be so fine as $0.3 \mu \mathrm{m}$ or less by the SEM observation. And it is supposed that other composites such as $\mathrm{Al}_{2} \mathrm{O}_{3}-\mathrm{SiC}, \mathrm{ZrO}_{2}-\mathrm{SiC}$ and Mullite-SiC can also be consolidated even including much volume of $\mathrm{SiC}$, when raw powders are fine enough in each case.

\section{Conclusions}

The powder mixture of $\mathrm{Si}_{3} \mathrm{~N}_{4}$ and additives having the specific surface area of $6.1 \mathrm{~m}^{2} / \mathrm{g}$ was milled using six kinds of the media balls, and the wear of the media balls was measured.

(1) The material with the least wear was $\alpha^{\prime} / \beta^{\prime}$ SiAlON.

(2) The specific surface srea of $6.1 \mathrm{~m}^{2} / \mathrm{g}$ of the initial powder increased to about $24 \mathrm{~m}^{2} / \mathrm{g}$ after $72 \mathrm{~h}$ milling.

(3) $\mathrm{SiC}$ ball wore rather much. The milled powder resulted in the composite of $\mathrm{Si}_{3} \mathrm{~N}_{4}$ with $13 \mathrm{vol} \%$ of $\mathrm{SiC}$ consolidated to almost full density by the conventional gas pressure sintering.

\section{References}

1) T. P. Herbell, M. R. Freedman and J. D. Kiser, Ceram. Eng. Sci. Proc., 6, 1124-34 (1985).

2) T. P. Herbell, M. R. Freedman and L. D. Kiser, ibid., 7, 817-27 (1986)

3) Y. Kuwahara, Y. Kanno and K. Suzuki, Funsai, No. 29, 115-18 (1985)

4) Y. Kanno, ibid., No. 30, 4-9 (1986).

5) S. Wada, N. Watanabe and Y. Ukyo, JSPM, 37, 1074-77 (1990).

6) Y. Shiraki, "Seramikkusu-Seizo-Purosesu", Gihodo Shuppan Co., Ltd. (1978) pp. 144-46.

7) H. Masaki, N. Watanabe and S. Wada, JSPM, submitted.

8) S. Wada and N. Watanabe, Seramikkusu-Ronbunshi, 96, 599-602 (1988).

9) Y. Fukushige, Y. Hirata, M. Sagiyama and K. Shimada, Yogyo-Kyokai-Shi, 94, 604-06 (1986).

10) E. Tani, M. Nishijima, K. Kishi and S. Umebayashi, YogyoKyokai-Shi, 95, 917-20 (1987).

11) P. Greil, G. Petzow and H. Tanaka, Ceramics Int., 13, 19-25 (1987).

\footnotetext{
${ }^{*}$ References 3)-10) are written in Japanese.
} 